\title{
Salinity dependence of recruitment success of the sea star Asterias rubens in the brackish western Baltic Sea
}

\author{
Isabel Casties • Catriona Clemmesen • \\ Frank Melzner · Jörn Thomsen
}

Received: 24 January 2014/Revised: 8 December 2014 / Accepted: 6 January 2015/Published online: 14 January 2015

(c) Springer-Verlag Berlin Heidelberg and AWI 2015

\begin{abstract}
Salinity strongly influences development and distribution of the sea star Asterias rubens. In Kiel Fjord, located in the western Baltic Sea, A. rubens is the only echinoderm species and one of the main benthic predators controlling blue mussel (Mytilus edulis) abundance. However, Kiel Fjord with an average salinity of about 15 is located close to the eastern distribution boundary of $A$. rubens in the Baltic Sea. In this study, we combined field and laboratory investigations to test whether the salinity of Kiel Fjord is high enough to enable successful development of A. rubens. Sea star eggs were fertilized in vitro, and development was monitored in the laboratory at four salinities $(9,12,15$ and 18) for 10 weeks. At a salinity of 9, development ceased prior to the blastula stage. At a salinity of 12, no larvae reached metamorphosis. At higher salinities, larvae developed normally and metamorphosed into juvenile sea stars. Abundances of A. rubens larvae and settled juveniles were also observed in Kiel Fjord and correlated to salinity values measured from March until June during 6 years (2005-2010). Results revealed high $A$. rubens settlement rates only in 2009, the year when salinity was the highest and least variable during the period of spawning and larval development. It appears that only years with high and stable salinities permit recruitment of A. rubens in Kiel Fjord. Projected desalination of the Baltic Sea could shift the distribution of A. rubens in the western Baltic Sea north-westwards and may lead to
\end{abstract}

Communicated by H.-D. Franke.

I. Casties $(\varangle) \cdot$ C. Clemmesen · F. Melzner · J. Thomsen

Marine Ecology, GEOMAR Helmholtz Centre for Ocean

Research Kiel, 24105 Kiel, Germany

e-mail: icasties@geomar.de local extinction of a keystone species of the benthic ecosystem.

Keywords Asterias rubens - Salinity tolerance $\cdot$ Early development . Baltic Sea

\section{Introduction}

The echinoderm Asterias rubens is a widely distributed benthic predator of the boreal area. This osmoconforming species is one of the most euryhaline echinoderm species, tolerating salinities between 8 and 36 (Binyon 1961, 1962; Wolff 1968; Nauen 1978). A. rubens is the only echinoderm species to form large populations in the western parts of the brackish Baltic Sea. Hyposaline stress in this area, however, is correlated with reduced maximum size of $A$. rubens and a much shorter spawning season compared with North Sea populations (Kowalski 1955). The Baltic Sea is characterized by a strong salinity gradient. High river run-off causes a salinity decrease from west to east and a large vertical gradient between the low saline surface water and high saline bottom water (Hjalmarsson et al. 2008). The investigated A. rubens population from Kiel Fjord, Germany $\left(54^{\circ} 19.8^{\prime} \mathrm{N}\right.$; $10^{\circ} 9.0^{\prime} \mathrm{E}$ ), lives close to the species' absolute border of distribution, as no adults have been observed east of the island of Ruegen, Germany, $\left(54^{\circ} 22.9^{\prime} \mathrm{N} ; 12^{\circ} 17.8^{\prime} \mathrm{E}\right)$ with average salinities as low as 8 (Binyon 1961). In Kiel Fjord, Asterias rubens can occur in high abundances (up to 120 ind $\mathrm{m}^{-2}$ ) and is, along with cod (Gadus morhua) and the green crab (Carcinus maenas), one of the most important predators of the benthic community (Anger et al. 1977; Nauen 1978; Reusch et al. 1994; Enderlein and Wahl 2004). With a biomass of about 32,000 tons in 
Kiel Bay, A. rubens can eliminate up to $77 \%$ of the yearly Mytilus edulis recruitment on soft bottoms, and thus, prevent the habitat from becoming a blue mussel monoculture (Nauen 1978; Reusch and Chapman 1997). Any changes in A. rubens population density may therefore have large effects on the entire benthic ecosystem in this region of the Baltic Sea.

Since dispersal of $A$. rubens is primarily achieved by passive transport of the planktonic larval stages, the species' distribution mainly depends on the larval stages which are, moreover, most vulnerable to abiotic stress, and therefore, represent a bottleneck to recruitment (McEdward and Janies 1993; Sameoto and Metaxas 2008). The planktotrophic larval phase of $A$. rubens lasts for about 9-12 weeks at a temperature of $\sim 14{ }^{\circ} \mathrm{C}$. From the blastula stage, the larva develops through a gastrula and bipinnaria stage to a brachiolaria larva which attains the competence to attach itself onto a suitable hard substrate and to metamorphose into a juvenile sea star (Barker and Nichols 1983; Nichols and Barker 1984; Gondolf 2000; Haesaerts et al. 2003, 2005).

So far, successful fertilization of A. rubens from Kiel Fjord has been reported by Kowalski (1955) at a salinity of 15 , but no studies have dealt with the complete development and the inter-annual variation of larval abundances and settlement success in this area. It is unclear at present whether the recruitment of $A$. rubens in this region is driven allochthonously, i.e. via occasional upwelling of high saline waters containing larvae that originate from the Kattegat (Hansen et al. 1999; Saderne et al. 2013), or whether recruitment is mainly autochthonous with the entire life cycle of the species being completed under the low saline conditions prevailing in Kiel Fjord. Understanding the sensitivity of Baltic A. rubens to osmotic stress is of particular importance, as future climate change will most likely lead to reductions in the average surface water salinity in the western Baltic Sea. This would primarily result from an increase in freshwater supply (Graewe et al. 2013). Depending on the IPCC scenario (A1B vs. B1), Kiel Bay will most likely experience reductions in average surface salinity by ca. 2 to $<13$ within this century (Graewe et al. 2013).

In order to test the sensitivity of Kiel Fjord A. rubens recruitment to changes in salinity, we studied larval development at four different salinities in a laboratory trial. Additionally, larval abundance and settlement success were studied in relation to salinity in the field over a period of 2 and 6 years, respectively. We hypothesized that the sea star population in Kiel Fjord is able to reproduce even in the low saline conditions and that reproduction success differs strongly between years, being highest in years with high and stable salinity during the reproductive period.

\section{Materials and methods}

Laboratory studies

\section{Fertilization and larval rearing}

Adult individuals of the sea star Asterias rubens were collected from Kiel Fjord $\left(54^{\circ} 19.8^{\prime} \mathrm{N} ; 10^{\circ} 9.0^{\prime} \mathrm{E}\right)$ in May 2009. In the laboratory, the sea stars were transferred into separate 2-1 beakers containing $0.2 \mu \mathrm{m}$ filtered seawater (FSW) previously UV-radiated and filtered with a series of water filters (50, 20 and $5 \mu \mathrm{m}$ Polystar, Pumpen am Ziegelteich $\mathrm{GmbH}$, Kiel, Germany). Spawning was induced by injecting $0.5 \mathrm{ml}$ of a $0.1 \mu \mathrm{M}$ solution of 1-methyladenine (Sigma-Aldrich, Hamburg, Germany) in each arm of the sea star. Eggs (ca. $770 \mathrm{ml}^{-1}$ ) of three females were collected and fertilized at $15^{\circ} \mathrm{C}$ and an ambient salinity (S) of 14 by adding $50-100 \mu \mathrm{l}$ of sperm suspension (ca. $10^{6} \mathrm{ml}^{-1}$ ) of three males. After $2 \mathrm{~h}$, fertilization success was determined: $97.5 \%$ for one parental pair and 64-67\% for the other two pairs. Subsequently, all embryos were pooled in a glass beaker and then transferred into glass beakers filled with 21 of $0.2 \mu \mathrm{m}$ FSW to achieve an initial larval density of 10 individuals $\mathrm{ml}^{-1}$.

Larval development was followed for a maximum of 72 days at four different salinity levels: 9, 12, 15 and 18 ( $N=3$ cultures each). The salinity levels were adjusted with a WTW cond 315i and a WTW TETRACON 325 probe by addition of deionized water or artificial sea salt (Instant Ocean) to FSW from the Fjord. The experiment was performed at a constant temperature of $15{ }^{\circ} \mathrm{C}$ and a light/dark cycle of LD 12:12. Ambient air was supplied to the beakers continuously from a pressurized air supplying facility. Concentrations of ammonium in the water were monitored using $\mathrm{NH}_{4}$ tests (JBL, Neuhofen, Germany) and maintained below $0.2 \mathrm{mg} \mathrm{l}^{-1}$ by means of weekly water exchanges to provide an adequate water quality for the larvae. The water was exchanged for the first time after 4 weeks, and then, $25 \%$ of the beaker volume was carefully replaced weekly.

Starting on the fourth day after fertilization, larvae were fed daily suspended cells of the alga Rhodomonas $s p$. Algae densities were measured twice a week using a culture counter (Z2 Coulter ${ }^{\circledR}$ Particle count and size analyzer, Beckman Coulter ${ }^{\mathrm{TM}}$, Krefeld, Germany). Algae were added daily to maintain a concentration between 1,000 and 2,000 cells $\mathrm{ml}^{-1}$.

The number of surviving larvae in each treatment was counted every 3-4 days by carefully removing $10 \mathrm{ml}$ out of each culture vessel. Counted larvae were fixed in $4 \%$ paraformaldehyde (PFA) in FSW. The total body length of 10 specimens per treatment and time point were measured using a stereo microscope (Leica Microsystems $\mathrm{GmbH}$, 
Wetzlar, Germany) equipped with a Micro Publisher 3.3 RTV camera (QImaging, Surrey, BC, Canada) and the image analysis software Image Pro Plus 5.0.1. (Media Cybernetics, Rockville, MD, USA). Shrinking of larvae due to the fixation process was considered by comparing unfixed and fixed individuals.

\section{Salinity effects on juvenile sea star survival}

Juvenile sea stars of approximately $1.8 \mathrm{~mm}$ in diameter were collected from a Mytilus edulis reef, the most important natural hard substrate in Kiel Fjord, at a water depth of ca. $20 \mathrm{~cm}$ in July 2009. They were placed in groups of five ( $N=3$ replicates each) into plastic petri dishes (diameter $88 \mathrm{~mm}$ and height $12 \mathrm{~mm}$ ) containing $0.2 \mu \mathrm{m}$ FSW of four different constant salinities: 9, 12, 15, 18 and one non-constant treatment $(S=16.5-19)$ which contained Kiel Fjord water. Sea stars were fed small $M$. edulis of an appropriate size (mussel length $=$ ca. $0.5 \times A$. rubens diameter) collected from Kiel Fjord. The water was carefully replaced every 3-4 days. Survival was checked regularly by assessing movements of the tube feet. The experiment was conducted at a constant temperature of $15^{\circ} \mathrm{C}$ for 6 weeks.

Field studies in Kiel Fjord

\section{Larval abundance and development}

In order to analyse the larval appearance and development of A. rubens in Kiel Fjord, we collected plankton samples once a week from the pier of the GEOMAR Helmholtz Centre for Ocean Research Kiel $\left(54^{\circ} 19.8^{\prime} \mathrm{N} ; 10^{\circ} 9.0^{\prime} \mathrm{E}\right)$ in 2009 and 2010. For this purpose, a $200-\mu \mathrm{m}$ plankton net (Hydro-Bios, Kiel, Germany) with a diameter of $0.25 \mathrm{~m}$ was manually towed vertically through the water column starting at a water depth of about $6 \mathrm{~m}$, thus sampling about $0.3 \mathrm{~m}^{3}$ water volume. Counting, fixation and size determination of the larvae were carried out as described above.

\section{Larval settlement on artificial and natural substrata}

Annual settlement of $A$. rubens was monitored between 2005 and 2010. PVC panels $(N=6 ; 5 \mathrm{~cm} \times 5 \mathrm{~cm})$ were suspended at the GEOMAR pier at a depth of $1 \mathrm{~m}$. Although free-swimming larvae occur all over the water column, a positive phototaxis results in their accumulation in the upper metres. The panels had previously been roughened using grain 60 sandpaper and were exchanged monthly to count the settled larvae and metamorphosed juveniles of $A$. rubens.
Additionally, the abundance of juvenile sea stars was assessed and quantified on natural hard substrate in Kiel Fjord in 2009 and 2010. For this purpose, clumps of $M$. edulis were sampled from the field, and the associated sea stars were counted. We determined the number of investigated mussels per clump and estimated the free surface area of each clump to quantify sea star density.

\section{Salinity variability}

Salinity variability in Kiel Fjord was recorded on weekly cruises of the research vessel FK Polarfuchs from 2005 to 2010 using a CTD48 M probe (Sea and Sun technologies, Trappenkamp, Germany) at a location ca. $500 \mathrm{~m}$ from the A. rubens sampling station. The data for the upper 6-m water column were averaged for 1-m steps using MATLAB (The MathWorks, Massachusetts, USA).

Statistical analyses

Weekly salinity determinations of the monitored years were tested using Shapiro-Wilk's tests for normal distribution. Salinity variations were analysed using nonparametric Kruskal-Wallis test and multiple comparisons. For survival rates of the larvae, a log-rank test was used and for analysing field abundance data, and Mann-Whitney $U$ tests were performed using STATISTICA 8 (StatSoft, Tulsa, USA).

\section{Results}

Laboratory experiments

At salinity 9, all embryos died before reaching the blastula stage (day 2). At salinity 12 , the embryonic development was abnormal; blastulae showed deformations, were opaque in appearance and less active (Fig. 1). These abnormal specimens reached the gastrula stage and a few $(<5 \%)$ even the bipinnaria stage. However, the larvae died within 4 weeks, without having increased in mean body size (Fig. 2). Larvae reared at salinities 15 and 18 showed similar survival rates (log-rank test $p=0.688)$ and reached settlement. Mean body length increased up to 1,200 and $900 \mu \mathrm{m}$ before settlement, respectively (Table 1 ). In all three treatments $(12,15$ and 18$)$, we observed feeding activity as red Rhodomonas cells accumulated in the stomach. Successful settlement of brachiolaria larvae and metamorphosis into juvenile sea stars was observed at salinities 15 and 18 after week 10 (Fig. 2a).

In contrast to the results obtained for pelagic larval stages, no mortality was observed in juvenile sea stars in any of the salinity treatments during 6 weeks of exposure. 
Fig. 1 Larvae from salinity treatments $12(\mathbf{a}), 15$ (b) and 18 (c) 9 days after fertilization. Scale bar (a-c) $250 \mu \mathrm{m}$
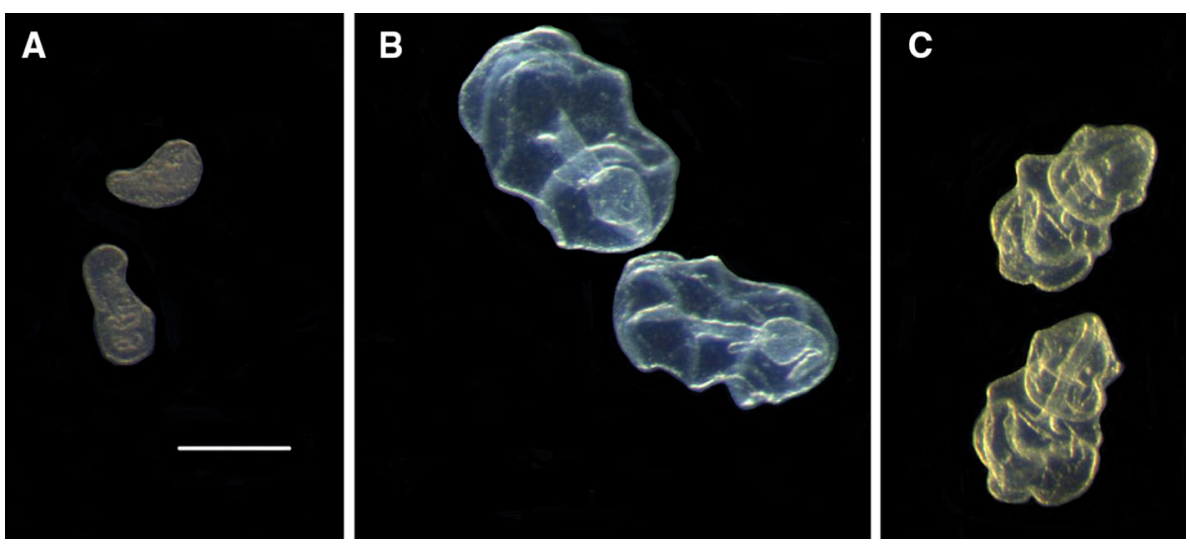

Field data
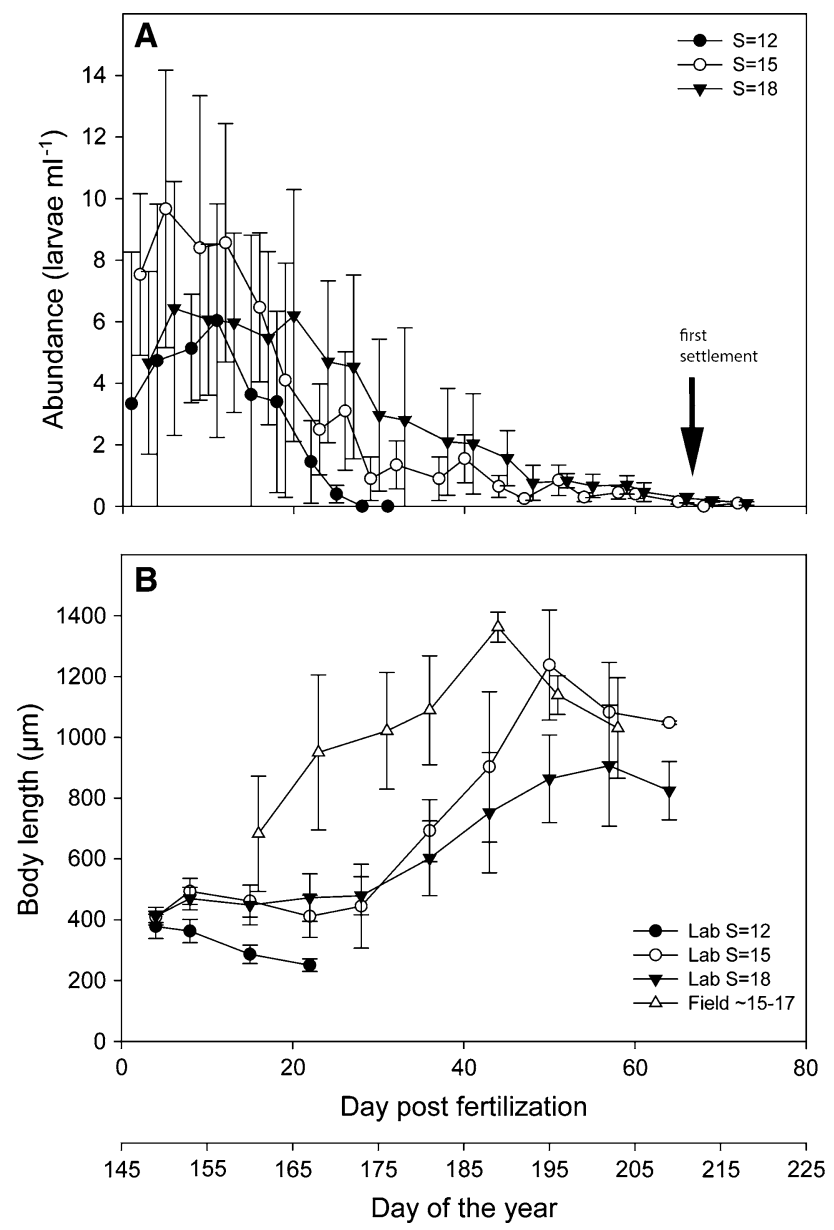

Fig. 2 a Survival curves (abundance: mean $\pm \mathrm{SD}, N=3$ each) for sea star larvae at three different salinities $(S=12,15$ and 18). The arrow marks the time when first settlement was observed. b Length of larvae (mean $\pm \mathrm{SD}, N=3$ each) at three different salinities $(S=12,15,18)$ in the laboratory and in the field $(S=15-17)$. The laboratory data are plotted against days post fertilization, the field data against calendar days. Experimental fertilization was carried out on calendar day 145

The experimental animals were observed to feed on the provided mussels in all treatments. Growth of juveniles was not monitored.
A comparison of the salinity data collected weekly over the sea star's reproductive period in Kiel Fjord between 2005 and 2010 revealed a strong inter-annual variance in mean salinity as well as a seasonal variability from March to June (Figs. 3, 4). The year 2008 was characterized by the lowest mean salinity over the reproductive period, whereas mean salinity values of all other years were higher (Fig. 3a). However, there were clear differences between the years. The year 2009 was characterized by relatively high mean salinity and the smallest seasonal variability compared with the other years [Kruskal-Wallis test $H(5,94)=27.3$, $p<0.05$ followed by multiple comparisons, Figs. 3b, 4]. In 2009 , salinity values were above 14 over the whole reproductive period relevant for the larval development of A. rubens (Figs. 3, 4).

In 2009, weekly plankton samples taken from Kiel Fjord revealed the ontogenetic shift from early gastrula to bipinnaria and finally the brachiolaria stages (Fig. 5). Gastrula stages were observed in May, first bipinnaria stages in June and settled juveniles in July. The density of collected larvae varied between 656 individuals $\mathrm{m}^{-3}$ at the beginning of June and 30 individuals $\mathrm{m}^{-3}$ in the middle of July. At the end of July, larvae of A. rubens were not found anymore. In 2010, in contrast, abundances of bipinnaria larvae $(U=6.5, p \leq 0.001)$ and brachiolaria larvae ( $U=21, p=0.008$ ) were much lower (Fig. 5). During the investigated period, mean body length of larvae in the settlement stage conformed to the values obtained in the laboratory (Fig. 2b; Table 1).

Successful settlement and metamorphosis of larvae on the settling panels were observed only in 2009. The mean number $( \pm \mathrm{SD})$ of settled $A$. rubens larvae on the PVC panels varied between $0.012 \pm 0.024$ and $0.72 \pm 0.24$ individuals $\mathrm{cm}^{-2}$ in the 4-week period from the middle of June to the middle of July (Fig. 5). In all other years between 2005 and 2010, no successful settlement of sea 
Table 1 Duration and size range $(\mu \mathrm{m})$ of different developmental stages of Asterias rubens of the three laboratory salinity treatments $(12,15$ and 18) and size range of larvae sampled from Kiel Fjord during the field study in 2009

\begin{tabular}{|c|c|c|c|c|c|c|c|}
\hline \multirow[t]{3}{*}{ Stage } & \multicolumn{6}{|c|}{ Experimental salinity treatment } & \multirow{3}{*}{$\begin{array}{l}\text { Kiel Fjord } \\
\text { Length }(\mu \mathrm{m})\end{array}$} \\
\hline & \multicolumn{2}{|l|}{12} & \multicolumn{2}{|l|}{15} & \multicolumn{2}{|l|}{18} & \\
\hline & Stage duration & Length $(\mu \mathrm{m})$ & Stage duration & Length $(\mu \mathrm{m})$ & Stage duration & Length $(\mu \mathrm{m})$ & \\
\hline Early bipinnaria & $\sim 20$ days & $250-370$ & 5 days & 410 & 5 days & 410 & \\
\hline Bipinnaria & & & 3 weeks & $410-490$ & 1 week & $450-470$ & $680-900$ \\
\hline Early brachiolaria & & & 2 weeks & $440-690$ & 3 weeks & $470-600$ & $950-1,360$ \\
\hline Brachiolaria & & & 3 weeks & $900-1,240$ & 4 weeks & $750-900$ & $950-1,360$ \\
\hline
\end{tabular}
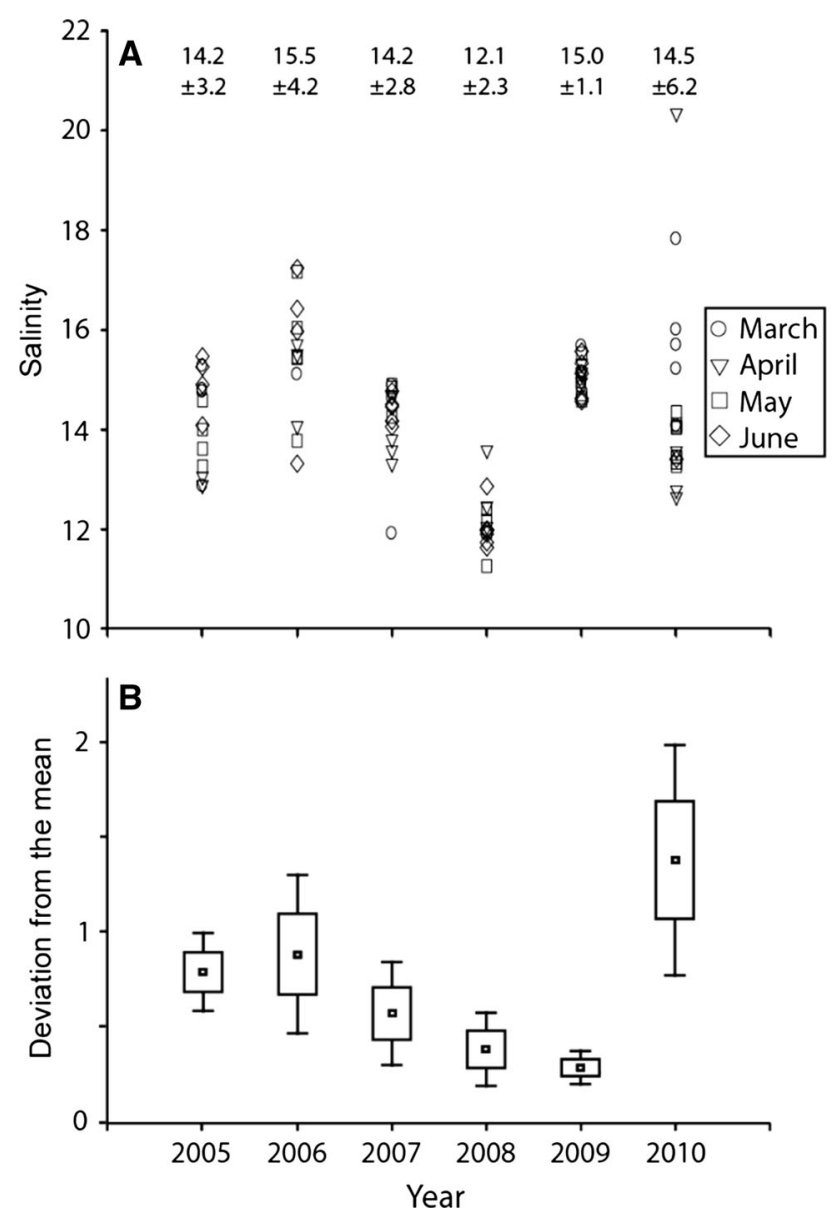

Fig. 3 Salinity of the upper $6 \mathrm{~m}$ layer in Kiel Fjord measured weekly from March until June for the years 2005 until 2010. a Mean \pm SD over the March-June periods is given for the different years with $N=16$ each. b The deviation of single salinity measurements from the mean

stars was observed on the panels. On mussel reefs, in contrast, low abundances of post-metamorphosed sea stars were found in 2010 as well. However, settlement densities were two orders of magnitude lower in comparison with 2009 (September $20090.23 \pm 0.11$ individuals $\mathrm{cm}^{-2}$

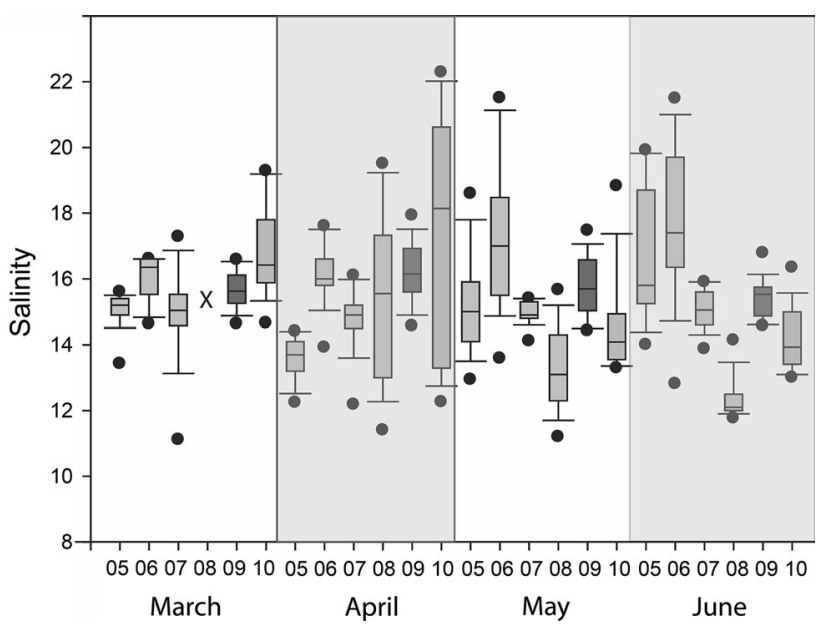

Fig. 4 Salinity of the upper $6 \mathrm{~m}$ layer in Kiel Fjord measured weekly from March until June for the years 2005 until 2010. The dark bars display the 2009 values with highest larvae abundance and settlement success. The line in each box represents the median, the bottom of the box depicts the 25 th percentile and the top the 75th percentile. The lower end of the whisker ends in the minimum and the upper in the maximum value. The black data points show outliers

mussel surface, September $20100.002 \pm 0.006$ individuals $\mathrm{cm}^{-2}$ mussel surface).

\section{Discussion}

The present study revealed that A. rubens is capable of completing its entire life cycle under the environmental conditions currently prevailing in Kiel Fjord. However, due to inter-annual salinity fluctuations in the Fjord, recruitment success drastically differed between the investigated years.

In the laboratory, the lowest tested salinity of 9 led to a complete arrest of larval development and $100 \%$ mortality within a few hours, whereas a salinity of 12 was tolerated by the sea star larvae for at least a short period of time ( $\sim 5$ days). Compared with $A$. rubens populations of the 


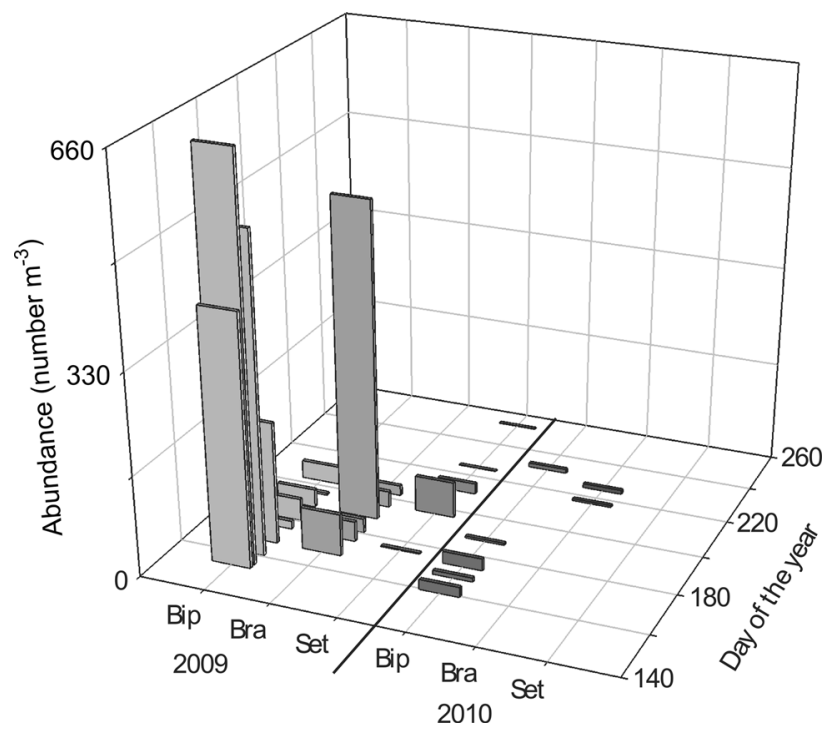

Fig. 5 Abundance of bipinnaria and brachiolaria larvae in water samples from Kiel Fjord and abundance of A. rubens settled on artificial panels in 2009 and 2010. Bip bipinnaria larvae, Bra brachiolaria larvae and Set settled sea stars

White Sea $(S=22-26)$ and the Barents Sea $(S=32-34)$, Kiel Fjord specimens tolerate lower salinities $(S \geq 14)$ (Saranchova and Flyachinskaya 2001; Sarantchova 2001). Although larvae of the salinity 12 treatment fed on Rhodomonas, their development was arrested in the bipinnaria stage. Either digestion was not accomplished or ion regulatory capacities failed to maintain intracellular ion and osmolyte homeostasis. Although sea stars are osmoconformers, they need to maintain a controlled intracellular inorganic ion composition, e.g. high $\left[\mathrm{K}^{+}\right]$and low $\left[\mathrm{Na}^{+}\right]$ (Diehl 1986). As a response to short-term hypo-osmotic stress, concentrations of inorganic ions and organic osmolytes decrease (Diehl and Lawrence 1985). Following the short-term response, intracellular ion concentrations, in particular $\left[\mathrm{K}^{+}\right]$, are restored to enable proper functioning of cellular, physiological processes (Diehl and Lawrence 1985). Due to the high trans-membrane transport activity, osmolaric adjustment is an energy-intensive process (Binyon 1972; Ellington and Lawrence 1974; Diehl 1986). Larvae of the salinity 12 treatment either lacked the required energy reserves to accomplish intracellular homeostasis, or the ion regulatory epithelia were not yet fully developed. In the latter case, disturbances of intracellular homeostasis may have led to lethal malformations. In contrast, larvae of the salinity 15 and 18 treatments successfully completed all developmental stages and metamorphosed into the benthic juvenile.

Sarantchova (2001) investigated population differences in salinity tolerance for different ontogenetic stages of Asterias rubens of the White Sea and the Barents Sea and observed a higher tolerance towards lower salinities in the
White Sea population, which is naturally exposed to lower salinities. The offspring of Barents Sea animals which had been acclimated to the lower White Sea salinity ( $S=24-26)$ showed survival rates similar to animals of the White Sea population (Sarantchova 2001). Obviously, a long-term acclimation to relative low salinities can increase the salinity tolerance at least in sea stars of the Barents Sea population.

Fertilization is regarded a very sensitive phase in the development of invertebrates, and the salinity tolerance has been reported to change during the early ontogeny by broadening in later larval stages of $A$. rubens (Saranchova and Flyachinskaya 2001; Sarantchova 2001; Kurihara 2008). In consistence with these findings, higher abundances of sea star larvae were observed in our study on $A$. rubens in the Kiel Fjord when the salinity over the spawning and fertilization period was high and constant.

Complete larval development could be achieved at salinities 15 and 18. In our laboratory experiment, a salinity of 14 was chosen for fertilization which corresponded to the conditions in Kiel Fjord on the same day (14.4). In Kiel Fjord, both strong seasonal fluctuations as well as interannual variations in salinity are encountered. The records for the 5 years studied showed salinity values between 10 and higher than 20 (Figs. 3, 4). At the beginning of the spawning time in 2009, salinity did not fall below 14.5. This year was characterized by both a relatively high mean salinity and a low variation in salinity values over the period of reproduction and early larval development. In all other years investigated, salinities were lower and more variable. As we observed high abundances of larvae and successful settlement only in 2009, we conclude that 2009 was a year of exceptionally favourable conditions for the reproduction of $A$. rubens in Kiel Fjord. The obtained results from laboratory and field studies suggest that the Kiel Fjord sea star population is self-sustainable under stable and relatively high salinity. However, when the salinity dropped below a critical threshold for an extended time during the sensitive spawning period, no or only few larvae reached the bipinnaria stage. According to the available settlement panel data from 2005 to 2010, significant recruitment occurred only in 2009. The low abundance of larvae in 2010 may be explained by a drift of older, more tolerant larval stages into the Fjord.

In contrast to the pelagic larvae, settled juvenile sea stars tolerated all salinity treatments $(9,12,15$ and 18) in the laboratory for at least 6 weeks, demonstrating a wider salinity tolerance range of metamorphosed ontogenetic stages.

According to future climate change scenarios, increasing precipitation and river run-off in the drainage area of the western Baltic Sea will probably reduce the salinity by up to 2 units (Helcom 2007; Graewe et al. 2013). Since 
salinity levels in Kiel Fjord already prevent reproduction of sea stars in most years, we can expect that fewer years will be suitable to facilitate a significant autochthonous recruitment of $A$. rubens in the future. Whereas Kiel Fjord sea stars may not be able to reproduce, a partial compensation is expected by allochthonous larval supply. However, a lower number of sea stars in this area may have strong repercussions on the benthic ecosystem (Nauen 1978; Enderlein and Wahl 2004). Other stressors that will concomitantly increase pressure on marine organisms, such as warming and ocean acidification (e.g. Appelhans et al. 2012), might additionally impact the fitness of $A$. rubens in the area.

Acknowledgments The authors thank Helgi Mempel, Michael Donner, Jesco Peschutter, Luise Töpfer and Matthias Paulsen for supplying the weekly salinity data and Hans-Harald Hinrichsen for processing these data. Further, we thank Martin Wahl and Renate Schütt for providing data on settlement success on settlement panels and Ulrike Panknin for Rhodomonas culturing efforts.

\section{References}

Anger K, Rogal U, Schriever G, Valentin C (1977) In-situ investigations on the echinoderm Asterias rubens as a predator of softbottom communities. Helgol Wiss Meeresunters 29:439-459

Appelhans YS, Thomsen J, Pansch C et al (2012) Sour times: seawater acidification effects on growth, feeding behaviour and acid-base status of Asterias rubens and Carcinus maenas. Mar Ecol Prog Ser 459:85-98

Barker MF, Nichols D (1983) Reproduction, recruitment and juvenile ecology of the sea star, Asterias rubens and Marthasterias glacialis. J Mar Biol Assoc UK 63:745-765

Binyon J (1961) Salinity tolerance and permeability to water of the sea star Asterias rubens L. J Mar Biol Assoc UK 41:161-174

Binyon J (1962) Ionic regulation and mode of adjustment to reduced salinity of the sea star Asterias rubens L. J Mar Biol Assoc UK 42:49-64

Binyon J (1972) The effects of diluted sea water upon podial tissues of the starfish Asterias rubens L. Comp Biochem Physiol 41A: $1-6$

Diehl WJ (1986) Osmoregulation in echinoderms. Comp Biochem Physiol 84A:199-205

Diehl WJ, Lawrence JM (1985) Effects of salinity on the intracellular osmolytes in the pyloric caeca and tube feet of Luidia clathrata (Say) (Echinodermata: Asteroidea). Comp Biochem Physiol 82A:559-566

Ellington WR, Lawrence JM (1974) Coelomic fluid volume regulation and isosmotic intracellular regulation by Luidia clathrata (Echinodermata: Asteroidea) in response to hyposmotic stress. Biol Bull 146:20-31

Enderlein P, Wahl M (2004) Dominance of blue mussels versus consumer-mediated enhancement of benthic diversity. J Sea Res 51:145-155
Gondolf AL (2000) Light and scanning electron microscopic observations on the developmental biology of the common sea star Asterias rubens Linné (Echinodermata: Asteroidea). Ophelia 52:153-170

Graewe U, Friedland R, Burchard H (2013) The future of the western Baltic Sea: two possible scenarios. Ocean Dyn 63:901-921

Haesaerts D, Jangoux M, Flammang P (2003) Study of the perimetamorphic period of the sea star Asterias rubens by scanning electron microscopy. In: Féral J-P, David B (eds) Echinoderm Research 2001, Swets and Zeitlinger, Lisse (The Netherlands), pp 155-159

Haesaerts D, Jangoux M, Flammang P (2005) The attachment complex of brachiolaria larvae of the sea star Asterias rubens (Echinodermata): an ultrastructural and immunocytochemical study. Zoomorph 124:67-78

Hansen HP, Giesenhagen HC, Behrends G (1999) Seasonal and longterm control of bottom-water oxygen deficiency in a stratified shallow-water coastal system. ICES J Mar Sci 56:65-71

HELCOM (2007) Climate change in the Baltic Sea Area - HELCOM Thematic Assessment in 2007. Balt Sea Environ Proc No 11

Hjalmarsson S, Wesslander K, Anderson LG et al (2008) Distribution, long-term development and mass balance calculation of total alkalinity in the Baltic Sea. Cont Shelf Res 28:593-601

Kowalski R (1955) Untersuchungen zur Biologie des Seesternes Asterias rubens L. in Brackwasser. Kiel Meeresforsch 11:201-213

Kurihara $\mathrm{H}$ (2008) Effects of $\mathrm{CO}_{2}$-driven ocean acidification on the early developmental stages of invertebrates. Mar Ecol Prog Ser 373:275-284

McEdward LR, Janies DA (1993) Life cycle evolution in asteroids: what is a larva? Biol Bull 184:255-268

Nauen CE (1978) The growth of the sea star, Asterias rubens, and its role as benthic predator in Kiel Bay. Kiel Meeresforsch Sonderheft 4:68-81

Nichols D, Barker MF (1984) Growth of juvenile Asterias rubens L. (Echinodermata: Asteroidea) on an intertidal reef in southwestern Britain. J Exp Mar Biol Ecol 78:157-165

Reusch TBH, Chapman ARO (1997) Persistence and space occupancy by subtidal blue mussel patches. Ecol Monogr 67:65-87

Reusch TBH, Chapman ARO, Groeger J (1994) Blue mussels Mytilus edulis do not interfere with eelgrass Zostera marina but fertilize shoot growth through biodeposition. Mar Ecol Prog Ser 108:265-282

Saderne V, Fietzek P, Herman PMJ (2013) Extreme variations of $\mathrm{pCO}_{2}$ and $\mathrm{pH}$ in a macrophyte meadow of the Baltic Sea in summer: evidence of the effect of photosynthesis and local upwelling. PLoS One 8(4):e62689. doi:10.1371/journal.pone. 0062689

Sameoto JA, Metaxas A (2008) Interactive effects of haloclines and food patches on the vertical distribution of 3 species of temperate invertebrate larvae. J Exp Mar Biol Ecol 367:131-141

Saranchova OL, Flyachinskaya LP (2001) The influence of salinity on early ontogeny of the mussel Mytilus edulis and the sea star Asterias rubens from the White Sea. Russ J Mar Biol 27:87-93

Sarantchova OL (2001) Research into tolerance for the environment salinity in sea starfish Asterias rubens L. from populations of the White Sea and Barentz Sea. J Exp Mar Biol Ecol 264:15-28

Wolff WJ (1968) The Echinodermata of the estuarine region of the rivers Rhine, Meuse, and Scheldt, with a list of species occurring in the coastal waters of the Netherlands. Neth J Sea Res 4:59-85 